PENERAPAN MODEL ARCS (ATTENTION, RELEVANCE, CONFIDENCE, SATISFACTION) DALAM PROSES PEMBELAJARAN PENDIDIKAN AGAMA ISLAM (PAI) DI SMK MUARA ILMU DEPOK”

\title{
Dede Setiawan
}

Prodi Pendidikan Agama Islam, Fakultas Agama Islam, Universitas Nahdlatul Ulama Indonesia

E-mail: dewa@unusia.ac.id

\section{Nur Kabibullah}

Prodi Pendidikan Guru Madrasah Ibtidaiyah, Fakultas Agama Islam, Universitas

Nahdlatul Ulama Indonesia

E-mail: habib79@unusia.ac.id

\section{Imam Sodiqul Wadi}

Prodi Pendidikan Agama Islam, Fakultas Agama Islam, Universitas Nahdlatul Ulama Indonesia

E-mail: $\underline{\text { imam_wadi@gmail.com }}$

\section{Article Information}

Informasi Artikel

Naskah diterima : 28

February 2020

Naskah direvisi: 13 Maret 2020

Naskah disetujui : 27

Maret 2020

Naskah dipublish: 10 April 2020

$\begin{array}{lr}\text { Kata } & \text { Kunci } \\ \text { Implementation, } & \text { ARCS } \\ \text { Model, } & \text { Islamic } \\ \text { Education, } & \end{array}$

$\begin{array}{lr}\text { Kata } & \text { Kunci } \\ \text { Implementasi, } & \text { Model } \\ \text { ARCS, Pendidikan } & \text { Agama Islam }\end{array}$

\section{Abstact}

This study aims to find out how to implement the ARCS (Attention, Relevance, Confidence, Satisfaction) motivation model in the learning process. This research is a qualitative research. The results showed that the implementation of the ARCS model (Attention, Relevance, Confidence, Satisfaction) in the study of Islamic Religion at SMK Muara Ilmu Depok, namely; First, the teacher always tries to arouse students' attention to the lesson by using various learning methods. Second, trying to show the relationship of the material learned with the needs of students by expressing learning objectives, benefits and showing the nature of enthusiasm. Third, increase students' confidence in their abilities by providing hope of success, systematic learning arrangement from easy to complicated and sequential material where one material can support the next material, such as the thaharah chapter given first before the prayer chapter and giving feedback that is constructive. Fourth, create student satisfaction by giving praise, giving opportunities to show their abilities, and opportunities to help friends who have not mastered.

\section{Abstrak}

Penelitian ini bertujuan untuk mengetahui bagaimana cara implementasi model motivasi ARCS (Attention, Relevance, Confidence, Satisfaction) dalam proses pembelajaran di SMK Muara Ilmu Depok. 
Penerapan Model Arcs (Attention, Relevance, Confidence, Satisfaction) Dalam Proses Pembelajaran Pendidikan Agama Islam (PAI)

Penelitian ini merupakan penelitian kualitatif. Hasil penelitian menunjukan bahwa implementasi model ARCS (Attention, Relevance, Confidence, Satisfaction) dalam pembelajaran Agama Islam di SMK Muara Ilmu Depok, yaitu; Pertama, guru senantiasa berusaha membangkitkan perhatian peserta didik terhadap pelajaran dengan cara menggunakan metode pembelajaran yang bervariasi; Kedua, berusaha menunjukan hubungan materi yang dipelajari dengan kebutuhan peserta didik dengan cara mengungkapkan tujuan pembelajaran, manfaat dan menunjukan sifat antusiasme. Ketiga, meningkatkan kepercayaan diri peserta didik akan kemampuannya dengan memberikan harapan keberhasilan, penyusunan pembelajaran secara sistematis dari materi yang mudah ke yang rumit dan berurutan dimana materi yang satu dapat menunjang materi yang berikutnya, seperti bab thaharah diberikan dahulu sebelum bab shalat dan memberikan umpan balik yang konstruktif. Keempat, menciptakan kepuasan peserta didik dengan memberikan pujian, memberikan kesempatan menunjukan kemampuannya, dan kesempatan membantu temannya yang belum menguasai.

\section{PENDAHULUAN}

Undang-undang Republik Indonesia Nomor 20 Tahun 2003 Tentang Sistem Pendidikan Nasional (SISDIKNAS), bahwa setiap peserta didik pada satuan pendidikan berhak mendapatkan pendidikan agama sesuai dengan agama yang dianutnya dan diajarkan oleh pendidik yang seagama ${ }^{1}$.

Pendidikan agama Islam harus merupakan system yang mengarah pada terbentuknya karakter, sikap dan perilaku peserta didik dengan syarat nilai-nilai Islam. Dengan demikian agama Islam seharusnya bisa mengembangkan kualitas keberagamaan Islam yang baik bersifat efektif, kognitif maupun psikomotorik.

Prof. Dr. M. Athiyah Al-Abrasyi, "Pembentukan moral yang tinggi adalah tujuan-tujuan utama dari pendidikan Islam”. Sebelumnya beliau menyatakan : Pendidikan budi pekerti adalah jiwa dari pendidikan Islam dan Islam telah menyimpulkan bahwa pendidikan budi pekerti dan akhlak adalah jiwa pendidikan Islam. Mencapai suatu akhlak yang sempurna adalah tujuan yang sebenarnya dari

\footnotetext{
1 Himpunan Perundang-undangan Republik Indonesia Tentang Sistem Pendidikan Nasional
} (SISDIKNAS) Nomor 20Tahun 2003, (Bandung, Nuansa Aulia, 2010), hal6. 
Penerapan Model Arcs (Attention, Relevance, Confidence, Satisfaction) Dalam Proses Pembelajaran Pendidikan Agama Islam (PAI)

pendidikan. Tapi ini tidak berarti bahwa kita tidak mementingkan jasmani atau akal atau ilmu ataupun segi-segi praktis lainnya tetapi artinya ialah bahwa kita memperhatikan segi-segi pendidikan akhlak seperti juga segi-segi lainnya itu ${ }^{2}$.

Pada realita yang ada didunia pendidikan, masih didapatkan peserta didik yang memandang sebelah mata pada pendidikan agama Islam. Peserta didik hanya menghafal, bukan mengerti, memahami, menghayati atau mengamalkan isi kandungan pendidikan agama Islam (PAI) dirasakan masih rendah dikalangan peserta didik SMK Muara Ilmu, perlu adanya dorongan yang memicu adanya keingintahuan dari setiap peserta didik dalam belajar agama Islam.

Salah satu peran guru menjadi motivator peserta didik, guna mendorong siswa dalam meningkatkan kegairahan dan mengembangkan kegiatan belajar siswa. Guru harus mengetahui motif-motif yang menyebabkan daya belajar siswa menurun. Guru harus merangsang dan memberi dorongan untuk membangkitkan kembali gairah dan semangat belajar siswa. Proses pembelajaran akan lebih berhasil jika siswa memiliki motivasi dalam belajar maka guru dituntut untuk kreatif memban gitkan motivasi belajar siswa.

Kurangnya sarana prasarana juga menjadi faktor penunjang dalam proses belajar mengajar di SMK Muara Ilmu Depok, sehingga dapat memicu kurangnya minat belajar siswa. Para pendidik telah meningkatkan pembelajaran agama supaya terjadi perubahan yang mendasar pada prestasi belajar siswa baik secara kognitif, afektif maupun psikomotorik. Namun pada kenyataannya prestasi belajar siswa terutama pendidikan agama Islam di SMK Muara Ilmu, dirasakan masih kurang memuaskan.

Keller telah menyusun seperangkat prinsip-prinsip motivasi yang dapat diterapkan dala proses pembelajaran, yang disebut ARCS model yaitu Attention (Perhatian), Relevance (Relevansi), Confidence (Percaya diri) dan Satisfaction (Kepuasan) $)^{3}$. Para pendidik diharapkan menerapkan prinsip motivasi tersebut dalam proses pembelajaran, mengingat kunci yang mengkondisikan peserta didik dalam pembelajaran adalah guru.

\footnotetext{
${ }^{2}$ Abu Ahmadidan Nur Uhbiyati, Ilmu Pendidikan, (Jakarta: PT. RINEKA CIPTA, 2001), hal. 112.

${ }^{3}$ Evline Siregar dan Hartini Nara, Teori Belajar dan Pembelajaran, (Jakarta:Ghalia Indonesia, 2010), hal. 52
} 
Penerapan Model Arcs (Attention, Relevance, Confidence, Satisfaction) Dalam Proses

Pembelajaran Pendidikan Agama Islam (PAI)

\section{METODOLOGI PENELITIAN}

Penulis dalam penelitian menggunakan penelitian kualitatif, penelitian kualitatif merupakan penelitian yang dilakukan berdasarkan paradigm, strategi dan implementasi model secara kualitatif. Bodgan dan Taylor mendefinisikan metodologi kualitatif sebagai prosedur penelitian yang menghasilkan data deskriptip berupakata-kata tertulis atau lisan dari orang-orang dan perilaku yang dapat diamati. Kirk dan Miller mendefinisikan bahwa penelitian kualitatif adalah tradisi tertentu dalam ilmu pengetahuan sosial yang secara fundamental bergantung pada pengamatan manusia dalam kawasannya sendiri dan berhubungan dengan orang-orang tersebut dalam bahasanya dan peristilahannya ${ }^{4}$.

\section{MODEL ARCS DALAM PEMBELAJARAN}

Model Pembelajaran Adalah Unsur Penting Dalam Kegiatan Belajar Mengajar Untuk Mencapai Tujuan Pembelajaran. Model Pembelajaran Digunakan Guru Sebagai Pedoman Dalam Merencanakan Pembelajaran Di Kelas. Joyce \& Weil Berpendapat Bahwa Model Pembelajaran Adalah Suatu Rencana Atau Pola Yang Dapat Digunakan Untuk Membentuk Kurikulum (Rencana Pembelajaran Jangka Panjang), Merancang Bahan-Bahan Pembelajaran, Dan Membimbing Pembelajaran Di Kelas Atau Yang Lain. ${ }^{5}$

Adi Memberikan Definisi Model Pembelajaran Merupakan Kerangka Konseptual Yang Menggambarkan Prosedur Dalam Mengorganisasikan Pengalaman Pembelajaran Untuk Mencapai Tujuan Pembelajaran. Model Pembelajaran Berfungsi Sebagai Pedoman Guru Dalam Merencanakan Dan Melaksanakan Kegiatan Pembelajaran. ${ }^{6}$

Winataputra mengartikan model pembelajaran sebagai kerangka konseptual yang melukiskan prosedur yang sistematis dalam mengorganisasikan pengalaman belajar untuk mencapai tujuan belajar tertentu dan berfungsi sebagai pedoman bagi

\footnotetext{
${ }^{4}$ Ba srowi dan Suwandi, Memahami Penelitian Kualitatif, (Jakarta: Rineka CIpta 2008), hal 20-21.

${ }^{5}$ Rusman, Model-model pembelajaran mengembangkan profesionalismeguru (Jakarta: Rajawali press, 2012),hal. 133

${ }^{6}$ Suprihatiningrum, Strategipembelajaran : teori dan aplikasi (Yogyakarta: Ar-ruzz Media, 2013),hal. 142
} 
Penerapan Model Arcs (Attention, Relevance, Confidence, Satisfaction) Dalam Proses Pembelajaran Pendidikan Agama Islam (PAI)

perancang pembelajaran dan para guru dalam merencanakan dan melaksanakan aktivitas belajar-mengajar. ${ }^{7}$

Secara sederhananya model pembelajaran adalah perencanaan atau suatu pola yang digunakan dalam merencanakan pembelajaran dikelas model tersebut merupakan pola umum perilaku pembelajaran untuk mencapai kompetensi/tujuan pembelajaran yang diharapkan. Model pembelajaran dapat pula disebut pola interaksi siswa dengan guru di dalam kelas yang menyangkut pendekatan ,strategi, metode, tekhnik pembelajaran yang diterapkan dalam pelaksanaan kegiatan belajar mengajar. Dalam suatu model pembelajaran di tentukan bukan hanya apa yang garus dilakukan guru, akan tetapi meny angkut tahapan - tahapan, prinsip - prinsip reaksi guru dan siswa serta system penunjang yang disyaratkan.

Keller telah menyusun seperangkat prinsip-prinsip model pembelajaran, yang disebut sebagai ARCS model, yaitu Attention (perhatian), Relevance (relevansi), Confidence (kepercayaan diri) dan Satisfaction (kepuasan). Dalam proses belajar dan pembelajaran.

Keempat motivasi tersebut sangatlah penting dipraktikkan untuk terus dijaga sehingga motivasi siswa terpelihara selama proses belajar dan pembelajaran berlangsung. Untuk mengetahui lebih lanjut mengenai model ARCS, maka penulis menguraikan sebagai berikut:

\section{Attention (Perhatian)}

Perhatian yaitu keaktifan jiwa yang diarahkan pada suatu objek, baik didalam maupun diluar dirinya ${ }^{8}$. Perhatian juga dapat didefinisikan sebagai suatu strategi kognitif yang mencakup empat keterampilan, yaitu : 1) berorientasi kepada suatu masalah, 2) meninjau sepintas masalah, 3) memisahkan diri pada aspek-aspek yang relevan, 4) mengabaikan stimuli yang tidak relevan ${ }^{9}$.

Perhatian itu merupakan reaksi umum dari organisme dan kesadaran, yang menyebabkan bertambahnya aktivitas, daya konsentrasi dan pembatasan kesadaran terhadap suatu objek ${ }^{10}$.

\footnotetext{
${ }^{7}$ Suyanto, Asep Jihad, Menjadi guru professional, (Jakarta:Erlangga, 2013),hal. 134

${ }^{8}$ Abu Ahmadi, Psikologi Umum, (Jakarta:Rineka Cipta, Cet.2, 1998), hal.145.

${ }^{9}$ Toeti Soekamto dan Udin Saripudin Winataputra, Teori Belajar dan Model-model Pembelajaran, (Jakarta:PAU-PPAI, 1996), Cet.2, hal. 47.

${ }^{10}$ Kartini Kartono, Psikologi Umum, (Bandung: Mandar Maju, 1996), hal. 11.
} 
Penerapan Model Arcs (Attention, Relevance, Confidence, Satisfaction) Dalam Proses Pembelajaran Pendidikan Agama Islam (PAI)

Perhatian (attention) adalah pemusatan atau pemfokusan usaha mental. Memusatkan perhatian kepada stimuli tertentu yang dianggapnya penting dan mengabaikan stimuli yang tidak penting (selektif). Sedangkan pada saat memperhatikan suatu hal tertentu, perhatian dapat beralih ke hal yang lain. Peserta didik dapat kapan saja mengalihkan perhatiannya dari materi atau satu hal ke hal lain atas kemauannya sendiri tanpa perlu ada perangsangan eksternal untuk mengalihkan perhatiannya(beralih). Rasa ingin tahu seseorang ini muncul karena dirangsang melalui elemen-elemen baru, aneh, lain dengan yang sudah ada, dan kontradiktif atau kompleks ${ }^{11}$.

Islam memandang perhatian sebagai tindakan penting dan sikap acuh (tidak mau memperhatikan) merupakan aktivitas yang tidak terpuji dan merupakan tanda tidak bersyukur kepada Allah S.W.T ${ }^{12}$. Perhatian didalam proses belajar mengajar merupakan factor utamayang jelas besar pengaruhnya. Artinya, peserta didik yang mau belajar harus memiliki atensi atau perhatian terhadap materi yang akan dipelajari ${ }^{13}$. Dengan adanya perhatian yang besar, maka peserta didik dapat menerima dan memilih stimuli yang relevan untuk diproses lebih lanjut diantara sekian banyak stimuli yang datang dari luar.

Perhatian peserta didik dalam proses pembelajaran berbeda-beda antara yang satu dengan yang lain. Ada yang dapat mempertahankan perhatian itu dari awal pelajaran sampai berakhirnya pelajaran. Ada yang hanya memperhatikan pada saat awal pelajaran, bahkan adapula yang sama sekali tidak memusatkan perhatian dari awal sampai akhir.

Kesadaran yang menyertai sesuatu ativitas atau pengalaman batin, dapat dibagi menjadi dua, yaitu; 1) perhatian intesif dan 2) perhatian tidak intensif ${ }^{14}$. Semakin banyak kesadaran yang menyertai suatu aktivitas atau pengalaman batin berarti semakin intensif perhatiannya, sedangkan jika makin intensif perhatian yang menyertai suatu aktivitas maka akan sukseslah aktivitas tersebut.

\footnotetext{
${ }^{11}$ Eveline Siregar, Hartini Nara, Teori Belajar dan Pembelajaran, (Jakarta: Ghalia Indonesia, 2010), ha1.52.

${ }^{12}$ Tohirin, Psikologi Pembelajaran Pendidikan Agama Islam. (Jakarta: Raja Grafindo Persada, 2006) hal. 130.

${ }^{13}$ R. Angkowo, dan A. Kosa sih, Optimalisasi Media Pembelajaran, (Jakarta: Grasindo, 2007), hal. 39.

${ }^{14}$ Sumadi Suryabrata, Psikologi Pendidikan, (Jakarta: Grafindo Persada, 2006), hal. 14.
} 
Penerapan Model Arcs (Attention, Relevance, Confidence, Satisfaction) Dalam Proses Pembelajaran Pendidikan Agama Islam (PAI)

Perhatian dapat dipengaruhi oleh beberapa factor yang dapat dibagi dalam dua golongan besar, yaitu faktor luar dan faktor dalam. Termasuk dalam factor luar adalah faktor-faktor yang terdapat pada objek yang diamati itu sendiri, yaitu intensitas, ukuran, kontras, pengulangan dan gerakan. Sedangkan termasuk dalam faktor dalam adalah faktor-faktor yang terdapat didalam diri individu si pen gamat, yaitu motif, kesediaan dan harapan.

Oleh karena itu, guru harus membangkitkan dan memelihara minat atau perhatian peserta didik guna menumbuhkan keingintahuan peserta didik dalam setiap mengikuti kegiatan pembelajaran.

Perhatian peserta didik dapat bangkit antara lain karena dorongan ingin tahu, karena itu rasa ingin tahu peserta didik perlu dirangsang. Setiap peserta didik perlu ditumbuhkan pertanyaan-pertanyaan reflektif di dalam dirinya, seperti "mengapa saya harus belajar tentang ini?". Demikian, perhatian akan terpelihara selama proses pembelajaran berlangsung ata bahkan lebih lama lagi ${ }^{15}$. Rasa ingin tahu peserta didik dapat dirangsang melalui cara-cara baru, unik, atau cara yang sudah ada.

\section{Relevance (Kegunaan)}

Relevance merupakan adanya hubungan yang ditujukan antara materi pembelajaran, kebutuhan dan kondisi siswa, yaitu berhubungan dengan kehidupan peserta didik baik berupa pengalaman sekarang atau yang telah dimiliki maupun yang berhubungan dengan kebutuhan karir sekarang atau yang akan datang, demikian menurut Keller ${ }^{16}$.

Sebagai peserta didik yang mulai belajar dikelas, mereka membawa sikap dan kebutuhan-kebutuhan. Keduanya, sikap dan kebutuhan mempengaruhi motivasi dan partisipasi didalamnya ${ }^{17}$. Jika peserta didik merasa kegiatan pembelajaran y ang mereka ikuti memiliki nilai, bermanfaat dan berguna bagi kehidupan mereka, maka akan terdorong mempelajarinya karena memiliki relevansi dengan kebutuhan mereka, dan memiliki tujuan yang jelas.

Sesuatu yang memiliki arah tujuan dan sasaran yang jelas serta memiliki manfaat yang relevan dengan kehidupan, akan mendorong individu untuk mencapai

\footnotetext{
${ }^{15}$ R. Angkowo, dan A. Kosasih, Optimalisasi Media Pembelajaran, (Jakarta: Grasindo, 2007), hal. 39. ${ }^{16}$ Eveline Siregar, Hartini Nara, Teori Belajar dan Pembelajaran, (Jakarta: Ghalia Indonesia, 2010), hal.52

${ }^{17}$ Sri Esti WuryaniDjiwandono, Psikologi Pendidikan, (Jakarta: Grasindo, 2002), hal. 361-362.
} 
Penerapan Model Arcs (Attention, Relevance, Confidence, Satisfaction) Dalam Proses Pembelajaran Pendidikan Agama Islam (PAI)

tujuan tersebut. Dengan tujuan yang jelas, mereka akan mengetahui kemampuan apa yang akan dimiliki dan pengalaman apa yang akan didapat. Mereka juga akan mengetahui kesenjangan antara kemampuan baru itu kebutuhan pribadi (basic needs) dikelompokan kedalam tiga kategori sebagai berikut ${ }^{18}$ :

a) Nilai motif pribadi (Personal Motive Value) mencakup kebutuhan untuk berprestasi (needs for achieviement), kebutuhan untuk berkuasa (needs for power) dan kebutuhan untuk berafiliasi atau berteman (needs for affiliation).

b) Nilai motif instrumental, berarti keberhasilan dalam mengerjakan tugas dianggap sebagai indikasi atau langkah untuk mencapai keberhasilan berikutnya.

c) Nilai motif kultural, berarti tujuan yang ingin dicapai itu sesuai dengan nilai yang diyakini dan dipegang oleh kelompok yang menjadi acuan peserta didik.

\section{Confidence (Percaya Diri)}

Rasa percaya diri (self-esteem) adalah dimensi evaluative yang menyeluruh dari diri. Rasa percaya diri juga disebut harga diri atau gambaran diri ${ }^{19}$. Secara terminology percaya diri adalah keyakinan yang dimiliki seseorang bahwa dirinya mampu menangani segala situasi dengan tenang ${ }^{20}$.

Tarsis Tarmuji mengatakan bahwa percaya diri adalah kemampuan untuk memecahkan problem secara kreatif, membuat orang lain merasa lega, melenyapkan rasa takut dan bimbang yang dapat memojokkannya jika membiarkannya ${ }^{21}$. Orang yang percaya pada dirinya sendiri akan merasa yakin terhadap kemampuan dirinya sehingga dapat menyelesaikan masalahnya karena mereka tahu apa yang dibutuhkan dalam hidupnya serta mempunyai sikap positif yang didasari keyakinan dan kemampuannya.

Diri merasa kompeten atau mampu, merupakan potensi untuk dapat berinterelasi dengan lingkungan. Bandura mengembangkan lebih lanjut konsep tersebut dengan mengajukan "self-efficacy". Konsep tersebut berhubungan dengan keyakinan pribadi bahwa dirinya memiliki kemampuan untuk melakukan suatu tugas yang menjadi syarat keberhasilan 22 .

\footnotetext{
${ }^{18}$ R. Angkowo, dan A. Kosasih, Optimalisasi Media Pembelajaran, (Jakarta: Grasindo, 2007), hal. 40.

${ }^{19}$ Jhon W. Santrock, Adolescence (Perkembangan Remaja), (Jakarta: Erla ngga, 2003), hal. 336.

${ }^{20}$ Ha mbly K., Bagaimana Meningkatkan Rasa Percaya Diri,. (Jakarta: Arcan, 1995), hal.3.

${ }^{21}$ Tarsis Tarmuji, Pengembangan Diri, (Yogyakarta:Liberty, 1998), hal. 47

${ }^{22}$ Sucia ti, Teori Belajar, Motivasi dan Keterampilan Mengajar, (Jakarta:PAUPAI, 1996), hal. 46.
} 
Penerapan Model Arcs (Attention, Relevance, Confidence, Satisfaction) Dalam Proses Pembelajaran Pendidikan Agama Islam (PAI)

Setiap orang bisa menjadi lebih percaya diri. Alasan utama kurang percaya diri adalah karena tidak mengetahui apa yang sebenarnya bisa dilakukan dan tidak mempunyai cukup pengalaman. Untuk memperjelas pengertian percaya diri, Zakiyah Darajat memberi gambaran tentang timbulnya percaya diri, yaitu apabila setiap rintangan dan halangan dapat dihadapi dengan sukses, sukses yang dicapai itu akan membawa kegembiraan, dan kegembiraa akan membawa kepercayaan diri selanjutnya kepercayaan diri akan dihadapi dengan hati yang tenang sehingga penganalisaan problem itu dapat dilakukan ${ }^{23}$.

Percaya diri banyak kaitannya dengan orang lain, kepercayaan pada diri sendiri itu ditentukan oleh pengalaman-pengalaman sejak kecil, sukses dan suasana menggembirakan akan menambah kepercayaan diri dan akan mempengaruhi pula sukses-sukses di masa yang akan datang, sebaiknya situasi dan kegagalan yang mengecewakan akan mempengaruhi kepercayaan pada diri dan akan mengakibatkan pula kegagalan-kegagalan yang berikutnya. Adapun lawan dari percaya diri adalah rendah diri ${ }^{24}$.

Kepercayaan diri berbanding lurus dengan konsep diri. Semakin baik konsep diri, maka akan semakin kuat percaya diri. Demikian sebaliknya, semakin buruk konsep diri, maka akan semakin lemah rasa percaya diri. Kepercayaan diri ini selanjutnya akan menentukan seberapa besar potensi atau kemampuan diri yang digunakan, seberapa baik dan efektifnya sebuah tindakan dan tentu saja akhirnya akan menentukan hasil yang didapatkan ${ }^{25}$.

Sikap percaya diri, yakin akan berhasil ini perlu ditanamkan pada peserta didik untuk mendorong mereka agar berusaha dengan maksimal guna mencapai keberhasilan yang optimal. Artinya untuk belajar secara efektif, perlu dihilangkan rasa kekhawatiran dan rasa ketidakmampuan dalam diri peserta didik. Peserta didik perlu percaya bahwa ia mampu dan bisa berhasil dalam mempelajari sesuatu. Oleh sebab itu, pada diri peserta didik perlu ditumbuhkan harapan positif untuk berhasil26.

\footnotetext{
${ }^{23}$ Zakiah Da rajat, Kesehatan Mental, (Jakarta: CV.Haji Ma sagung, 1990), hal. 25.

${ }^{24}$ Zakiah Da rajat, Kesehatan Mental, (Jakarta: CV. Haji Ma sagung, 1990), hal. 26.

25 Adi W. Gunawan, Genius Learning Strategi, Petunjuk Praktis Untuk Menerapkan Accelerated Learning, (Jakarta: Gramedia Pustaka Utama, 2004), cet. 2, hal. 47.

${ }^{26}$ R. Angkowo, dan A. Kosasih, Optimalisasi Media Pembelajaran, (Jakarta: Grasindo, 2007), hal. 41.
} 
Penerapan Model Arcs (Attention, Relevance, Confidence, Satisfaction) Dalam Proses Pembelajaran Pendidikan Agama Islam (PAI)

Prinsip yang perlu dikembangkan adalah bahwa motivasi itu akan tumbuh, berkembang, dan meningkat sejalan dengan tumbuh, berkembang dan meningkatnya harapan atau cita-cita untuk berhasil. Harapan atau cita-cita ini sering kali dipengaruhi oleh pengalaman keberhasilan masa sebelumnya. Motivasi dapat memacu dan menghasilkan ketekunan yang membawa serta mengarahkan keberhasilan (prestasi). Selanjutnya, pengalaman berhasil akan memotivasi seseorang untuk melaksanakan tugas berikutnya ${ }^{27}$.

Dengan demikian dapat dinyatakan bahwa sikap percaya diri merupakan sikap yakin bahwa dirinya benar, kuat dan mampu dalam menghadapi masalah yang akan datang. Mengingat betapa pentingnya rasa percaya diri, tugas guru untuk menumbuhkan rasa percaya diri pada peserta didik, sehingga mereka merasa mampu dalam setiap pelajaran apapun.

\section{Satisfaction (Kepuasan)}

Kepuasan adalah perasaan gembira, perasaan ini dapat positif timbul kalau orang mendapakan penghargaan terhadap dirinya ${ }^{28}$. Perasaan ini akan meningkat pada harga diri kelak. Keberhasilan dalam pencapaian suatu tujuan akan menghasilkan kepuasan, dan peserta didik akan termotivasi untuk terus berusaha mencapai tujuan yang serupa. Kepuasan karena mencapai tujuan dipengaruhi oleh konsekuensi yang diterima, baik yang berasal dari dalam, maupun yang berasal dari luar peserta didik. Untuk meningkatkan dan memelihara motivasi peserta didik, guru dapat menggunakan penguatan (reinforcemen) berupa pujian, pemberian kesempatan, dan sebagainya. ${ }^{29}$

Reinforcement atau penguatan yang dapat memberikan rasa bangga dan puas pada peserta didik adalah penting dan perlu dalam proses pembelajaran. Artinya bahwa motivasi belajar harus mampu menghasilkan rasa puas guna menyokong atau mendorong tumbuhnya keinginan untuk tetap belajar ${ }^{30}$. Misalnya guru memberikan pujian atau hadiah bagi peserta didik yang menunjukkan usaha yang baik, memberikan angka tinggi terhadap prestasi yang diraihnya. Tidak menyalahkan pekerjaan atau

\footnotetext{
${ }^{27}$ Eveline Siregar, Hartini Nara, Teori Belajar dan Pembelajaran, (Jakarta: Ghalia Indonesia, 2010), ha1.53.

${ }^{28}$ Bimo Walgito, Psikologi Umum, (Jogjakarta, FPSI-UGM, 1981), hal. 140.

${ }^{29}$ Sucia ti, Teori Belajar, Motivasi dan Keterampilan Mengajar, (Jakarta:PAUPAI, 1996), hal.48.

${ }^{30}$ R. Angkowo, dan A. Kosa sih, Optimalisasi Media Pembelajaran, (Jakarta: Grasindo, 2007), hal. 42
} 
Penerapan Model Arcs (Attention, Relevance, Confidence, Satisfaction) Dalam Proses

Pembelajaran Pendidikan Agama Islam (PAI)

jawaban peserta didik secara terbuka sekalipun pekerjaan atau jawaban tersebut belum memuaskan ${ }^{31}$.

Berikut dijelaskan pendapat ulama atau pakar pendidikan muslim mengenai pemberian ganjaran, antara lain:

a) Pendapat Al-Ghazali

Al-Ghazali berpendapat bahwa apabila anak memperlihatkan suatu kemajuan, akhlak terpuji atau perbuatan yang baik, sebaiknya guru memuji hasil upaya muridnya, berterimakasih kepadanya, dan mendukungnya di depan teman-temannya, guna menaikkan harga dirinya dan menjadikan sebagai model atau teladan yang harus diikuti $^{32}$.

b) Pendapat Ibnu Jama'ah

Menurut Ibnu Jama'ah, imbalan atau pujian lebih kuat dan berpengaruh terhadap pendidikan anak daripada sanksi atau hukuman. Sanjungan atau pujian guru dapat mendorong siswa untuk meraih keberhasilan atau prestasi yang lebih baikdan memotivasinya untuk berupaya serta berkompetisi secara sehat diantara sesama peserta $\operatorname{didik}^{33}$.

c) Pendapat Ibnu Khaldun

Ibnu Khaldun mengemukakan, bahwa barang siapa yang mendidik dengan kekerasan dan paksaan, maka peserta didik akan melakukan suatu perbuatan dengan terpaksa pula, menimbulkan ketidakgairahan jiwa, lenyapnya aktivitas, mendorong peserta didik untuk malas, berdusta dan berkata buruk ${ }^{34}$. Bentuk-bentuk kesuksesan yang dapat menghasilkan kepuasan antara lain: pekerjaan sukses, belajar berhasil, permainan menyenangkan, dan penyelesaian masalah. Rasa puas atau kepuasan atas hasil tertentu akan membuat peserta didik berusaha mengulangi kembali keberhasilan tersebut bahkan memberi daya dorong untuk berbuat kepada tingkat yang lebih tinggi dan berat.

Menurut Keller berdasarkan teori kebanggan, rasa puas dapat timbul dalam individu sendiri yang disebut kebanggaan instrinsik dimana individu merasa puas dan bangga telah berhasil mengerjakan, mencapai atau mendapat sesuatu. Kebanggaan dan

\footnotetext{
${ }^{31}$ H. Syaiful Sa gala, Konsep dan Makna Pembelajaran, (Bandung: Alfabeta, 2002), hal 101.

${ }^{32}$ Sya msu Yusuf LN., Psikologi Belajar Agama, (Bandung: Pustaka Bani Qura isy, 2005), hal. 98.

${ }^{33}$ Sya msu Yusuf LN., Psikologi Belajar Agama, (Bandung: Pustaka Bani Qura isy, 2005), hal. 99.

${ }^{34}$ Sya msu Yusuf LN., Psikologi Belajar Agama, (Bandung: Pustaka Bani Quraisy, 2005), hal. 100.
} 
Penerapan Model Arcs (Attention, Relevance, Confidence, Satisfaction) Dalam Proses Pembelajaran Pendidikan Agama Islam (PAI)

rasa puas ini juga dapat timbul karena pengaruh dari luar individu, dari orang lain atau lingkungan yang disebut kebanggaan eksrinsik ${ }^{35}$.

\section{IMPLEMENTASI Model ARCS}

\section{Attention (Perhatian)}

a) Mengetuk meja

Guru mengetuk meja pada saat perhatian siswa mulai tidak focus, seperti yang terjadi pada beberapa siswa ketika guru sedang menjelaskan pelajaran ada siswa yang mengobrol dengan teman nya, guru mengetuk meja kemudian perhatian siswa akan tertuju kembali kepada materi yang disampaikan guru.

b) Mengeraskan suara dalam menyampaikan materi pelajaran

Siswa yang duduk dideretan paling belakang biasanya akan mudah sekali mengalihkan perhatiannya pada saat guru menyampaikan materi, apabila suara guru dalam menyampaikan materi terdengar samara tau kurang terdengar maka siswa akan cenderung tidak memperhatikan materi yang disampaikan guru, dengan mengeraskan suara dalam menyampaikan materi pelajaran siswa dapat memperhatikan kembali dengan focus.

c) Menggunakan humor

Selama proses pembelajaran berlangsung, akan ada waktu dimana suasana kelas mulai tidak kondusif, menegangkan, dan menjenuhkan, maka guru menggunakan humor. Selain itu dalam penggunaan humor juga selalu memperhatikan suasana kelas semakin gaduh dan menyinggung peserta didik serta dapat mengalihkan perhatian mereka dari materi tersebut. Seperti yang dilakukan guru SMK Muara Ilmu Depok pada saat pembukaan pelajaran mengatakan "mengajar kali ini bapak ditemani gadis imut bernama Siti Fathimah, yaitu garis-garis, titik, bulatan, koma dan panah" sambil menunjuk pada LCD yang sudah terpasang.

d) Guru melibatkan siswa (berperan) dalam sebuah permainan.

Dengan cara guru memberikan topi kepada siswa yang duduk dibangku deretan depan sebelah kanan, kemudian topi itu diberikan kepada teman sebelahnya terus berurutan hingga pada siswa yang duduk di bangku deretan belakang sambil

\footnotetext{
${ }^{35}$ Eveline Siregar, Hartini Nara, Teori Belajar dan Pembelajaran, (Jakarta: Ghalia Indonesia, 2010), hal.53
} 
Penerapan Model Arcs (Attention, Relevance, Confidence, Satisfaction) Dalam Proses Pembelajaran Pendidikan Agama Islam (PAI)

bershalawat atau bernyanyi, jika shalawat atau nyanyian selesai kemudian topi berada pada siswa, maka siswa itu yang harus menjawab pertanyaan dari guru.

e) Guru tidak hanya duduk dikursi.

Dalam menyampaikan materi pelajaran guru tidak hanya duduk dikursi guru, melainkan berdiri dan berjalan mengelilingi siswa, kesamping, kedepan dan kebelakang.

f) Guru melibatkan siswa dengan cara meminta atau menyuruh siswa.

Guru melibatkan siswa untuk menuliskan suatu jawaban dari pertanyaan yang diberikan oleh guru dipapan tulis.

g) Guru meminta siswa membaca.

Guru meminta siswa membaca suatu kisah Nabi Ibrahim pada saat diperintahkan Allah S.W.T untuk menyembelih putranya Nabi Ismail, kemudian siswa diminta untuk membuat kesimpulan dari kisah yang telah dibaca.

h) Guru memberikan kesempatan kepada siswa untuk bertanya seputar materi yang disampaikan.

Dalam menyampaikan materi guru menyelangi dengan pertanyaan, "sampai disini penjelasan bapak, apakah ada pertanyaan?" atau "ada pendapat tentang materi ini?"

i) Guru menggunakan media pembelajaran atau praktik.

Guru menjelaskan bab thaharah (bersuci) dengan mempraktikan langsung, guru dalam menyampaikan materi pelajaran dibantu dengan media pembelajaran berupa LCD guna menarik perhatian siswa dan mempermudah guru dalam menyampaikan materi pelajaran.

j) Guru membagi siswa dalam beberapa kelompok, kemudian memberikan tugas kelompok.

Kelompok yang satu dengan kelompok yang lain diberikan tugas yang berbeda, ada siswa yang diminta menceritakan asal-usul diciptakannya manusia berikut dengan dalil Al-Qur'an, menceritakan kisah kelahiran Nabi Muhammad S.A.W, Nabi Isa A.S, Nabi Ibrahim A.S dan kisah Lukman kemudian siswa menuliskan apa yang mereka peroleh dari isi tugas tersebut.

k) Guru menegur siswa yang tidak memperhatikan. 
Penerapan Model Arcs (Attention, Relevance, Confidence, Satisfaction) Dalam Proses

Pembelajaran Pendidikan Agama Islam (PAI)

Menegur siswa pada proses pembelajaran berlangsung dengan cara bertanya "mengapa kamu tidak memperhatikan?".

1) Guru berdiri disamping siswa yang tidak focus atau merasa bosan.

Guru tidak hanya duduk dikursi guru pada saat menyampaikan materi pelajaran, dalam menyampaikan materi pelajaran guru berjalan sambil menhampiri siswa yang kurang memperhatikan kemudian berdiri sejenak dekat siswa yang tidak memperhatikan.

m) Guru meminta siswa mengulang kembali materi yang telah disampaikan dengan bahasa siswa.

Guru setelah menjelaskan materi tentang sejarah perkembangan Islam di Indonesia, kemudian guru meminta siswa untuk mengulanginya kembali penjelasan tersebut dengan bahasa mereka.

n) Guru memberikan pujian kepada siswa.

Guru memberikan pujian kepada siswa yang dapat menjawab pertanyaan yang diberikan guru dengan mengatakan "Iya... Betul, kamu hebat" sambil mengacungkan Ibu jari.

o) Meminta siswa untuk membantu guru.

Guru meminta siswa untuk menuliskan tambahan pelajaran di papan tulis.

p) Guru menyita hal-hal yang tidak berhubungan dengan materi pelajaran.

Guru menyita HP (Hand Phone) siswa dalam proses pembelajaran berlangsung dan mengembalikannya setelah selesai pembelajaran.

q) Guru memberi reward kepada siswa yang berhasil dalam belajar.

Guru memberikan soal ulangan harial kepada siswa dan siapa yang mendapatkan nilai paling tinggi, maka akan mendapatkan reward (hadiah) dari guru berupa pensil, pena, ataupun buku.

r) Guru melibatkan siswa dengan cara "Kuis".

Guru memberikan pertanyaan kepada siswa dengan memberikan persyaratan siapa saja yang dapat menjawab siswa terlebih dahulu mengangkatkan tangannya kemudian guru akan menunjuk siswa tersebut dan mempersilahkan untuk menjawab, apabila siswa tersebut menjawab salah maka pertanyaan akan dilemparkan kepada siswa yang lain sampai mendapatkan jawaban yang tepat. 
Penerapan Model Arcs (Attention, Relevance, Confidence, Satisfaction) Dalam Proses Pembelajaran Pendidikan Agama Islam (PAI)

\section{Relevance (Kegunaan)}

a) Guru menyampaikan tujuan pelajaran kepada siswa dengan ini siswa akan tahu kemana materi pelajaran mengarah, dengan demikian siswa akan lebih termotivasi lagi untuk giat belajar. Ini terlihat pada RPP guru bidang studi Pendidikan Agama Islam.

b) Guru menyampaikan manfaat materi pelajaran kepada siswa, apabila siswa mengetahui akan manfaat materi yang dijelaskan seperti materi thaharah (bersuci), pentingnya menjaga rasa persatuan dan kesatuan antar ummat. Yang diajarkan guru dapat terlihat pada siswa mampu mempraktikan bagaimana caranya bertayammum dan akhlak siswa terhadap siswa lain yang bukan satu sekolahan terlihat menjadi akrab yang dulunya pernah terlihat tawuran yang bermula dari saling ejek mengejek.

c) Antusias siswa dalam mengikuti pelajaran Pendidikan Agama Islam, dapat terlihat pada keaktifan siswa dalam mengikuti praktik tata cara tayammum, mengikuti acara maulid Nabi Muhammad S.A.W yang dimeriahkan dengan berbagai macam kegiatan mulai dari lomba melantunkan bacaan ayat-ayat suci Al-Qur'an, Adzan dan kegiatan-kegiatan lainnya yang bersifat Islami.

\section{Confidence (Percaya Diri)}

a) Guru memberikan pernyataan yang sifatnya membangun dengan mengatakan "kalian pasti bisa menjawab soal yang saya berikan", dengan memberikan pernyataan yang sifatnya membangun kepada siswa, maka dapat tumbuh rasa percaya diri siswa tersebut, kemudian guru memberikan pertanyaan kepada siswa dan siswa menjawab pertanyaan guru, walaupun jawabann ya salah.

b) Guru memberikan nilai langsung dan menuliskan dipapan tulis, berupa angka kepada siswa yang dapat menjawab pertanyaan dari guru dengan benar.

c) Guru menyusun pembelajaran dengan sedemikian rupa agar mudah dipahami oleh siswa dan sistematis.

\section{Satisfaction (Kepuasan)}

a) Pujian dapat memberikan kepuasan tersendiri bagi para siswa, terbukti pada saat peneliti bertanya secara lisan kepada beberapa siswa yang mendapat pujian dari guru, mereka mengatakan sangat senang karena mendapat pujian dari guru dari pada mendapat hukuman. 
Penerapan Model Arcs (Attention, Relevance, Confidence, Satisfaction) Dalam Proses Pembelajaran Pendidikan Agama Islam (PAI)

b) Gru memberikan kesempatan kepada siswa yang mampu untuk mempraktikkan tata cara pelaksanaan tayammum, kemudian salah satu siswa pun mempraktikkannya didepan kelas.

c) Guru meminta siswa yang sudah berhasil dalam pelafalan makhorijul huruf ketika membaca ayat-ayat Al-Qur'an, untuk membantu siswa yang belum berhasil atau belum bisa secara pasih dalam pelapalan makhorijul hurufnya.

\section{KESIMPULAN}

Berdasarkan penelitian yang dilakukan oleh penulis, dapat disimpulkan tentang penerapan model ARCS (Attention, Relevance, Confidence, Satisfaction) dalam proses pembelajaran Pendidikan Agama Islam di SMK Muara Ilmu Depok, sebagai berikut:

Guru senantiasa membangkitkan perhatian (Attention) peserta didik dengan menggunakan metode pembelajaran yang bervariasi, seperti: metode ceramah, umpan balik, Tanya jawab, demonstrasi, melibatkan peserta didik dalam pembelajaran dan lain sebagainya. Menggunakan alat media pembelajara yang bervariasi.

Berusaha menunjukan Relevance (Kegunaan) materi yang dipelajari dengan kebutuhan peserta didik dengan mengungkapkan tujuan dan intruksional, manfaat belajar PAI dan bersikap antusias dalam belajar.

Meningkatkan rasa kepercayaan diri (Confidence) peserta didik dengan memberikan pernyataan-pernyataan yang sifatnya membangun, memberikan nilai langsung kepada siswa, pemberian materi yang sistematis dari materi yang mudah hingga materi yang paling sukar.

Menciptakan rasa kepuasan (Satisfaction) peserta didik dengan memberikan pujian kepada peserta didik secara langsung, memberikan kesempatan kepada peserta didik untuk mempraktikan kemampuannya, meminta siswa yang sudah berhasil atau dianggap mampu dalam materi pelajaran untuk membantu temannya yang belum berhasil.

\section{DAFTAR PUSTAKA}

Abdul Majid dan Dian Andayani, Pendidikan Agama Islam Berbasis Kompetensi, Bandung: Remaja Rosdakarya, 2004.

Abu Ahmadi dan Nur Uhbiyati, Ilmu Pendidikan, Jakarta: PT. Rineka Cipta, 2001. Abu Ahmadi, Psikologi Umum, Jakarta: Rineka Cipta, Cet.2, 1998. 
Penerapan Model Arcs (Attention, Relevance, Confidence, Satisfaction) Dalam Proses

Pembelajaran Pendidikan Agama Islam (PAI)

Adi W. Gunawan, Genius Learning Strategi, Petunjuk Praktis Untuk Menerapkan Accelerated Learning, Jakarta: Gramedia Pustaka Utama, 2004.

Angkowo R., dan A. Kosasih, Optimalisasi Media Pembelajaran, Jakarta: Grasindo, 2007.

Basrowi dan Suwardi, Memahami Penelitian Kualitatif, Jakarta : PT Rineka Cipta, 2008.

Darajat Zakiyah, Ilmu Pendidikan Islam, Jakarta : Bumi Aksara, 1996.

Esti Sri Wuryani Djiwandono, Psikologi Pendidikan, Jakarta : Grasindo, 2002.

Eveline Siregar, Hartini Nara, Teori Belajar dan Pembelajaran, Jakarta: Ghalia Indonesia, 2010.

H. Syaiful Sagala, Konsep dan Makna Pembelajaran, Bandung: Alfabeta, 2002.

Hambly K., Bagaimana Meningkatkan Rasa Percaya Diri, . Jakarta: Arcan, 1995.

Herdiansyah Haris, Wawancara, Observasi dan Focus Groups Sebagai Instrumen

Penggalian Data Kualitatif, Jakarta : PT. Raja Grafindo Persada, 2013

Jalaludin, Teologi Pendidikan, Jakarta: Raja Grafindo Persada, 2000.

Jhon W. Santrock, Adolescence (Perkembangan Remaja), Jakarta: Erlangga, 2003.

Kartini Kartono, Psikologi Umum, Bandung: Mandar Maju, 1996.

Made Astra Winaya, Pengaruh Model ARCS Terhadap Hasil Belajar Ditinjau Dari Motivasi Belajar Siswa Pada Pembelajaran IPS Di Kelas IVSD Chis Denpasar, Singaraja: Universitas Pendidikan Ganesha, 2013.

Martinis Yamin, Kiat Membelajarkan Siswa, Jakarta: Gp. Press Group, 2013.

Muslam, Pengembangan Kurikulum PAI, Semarang, PKP12 2004.

Naim Ngainun dan Ahmad Patoni, Materi Penyusunan Desain Pembelajaran Pendidikan Agama Islam, Yogyakarta : Pustaka Pelajar. 2007

R. Angkowo, dan A. Kosasih, Optimalisasi Media Pembelajaran, (Jakarta: Grasindo, 2007).

Salim Haitami \& Samsul Kurniawan, Studi Pendidikan Islam, Jogjakarta :

Ar-Ruzz Media, 2012.

Soekamto Toeti dan Udin Saripudin Winataputra, Teori Belajar dan Model-Model

Pembelajaran, Jakarta : PAU-PPAI, Cet2, 1996.

Sri Esti Wuryani Djiwandono, Psikologi Pendidikan, Jakarta: Grasindo, 2002.

Suciati, Teori Belajar, Motivasi dan Keterampilan Mengajar, Jakarta: PAUPAI, 1996 
Penerapan Model Arcs (Attention, Relevance, Confidence, Satisfaction) Dalam Proses Pembelajaran Pendidikan Agama Islam (PAI)

Sulistiyani, Efektivitas Pembelajaran ARCS (attention, relevance, confidence, satisfaction) Berbantuan Alat Peraga Terhadap Peningkatan Hasil Belajar Matematika Peserta Didik Pada Pokok Bahasan Segi Empat, Semarang: IAIN WALISONGO, 2011.

Sumadi Suryabrata, Psikologi Pendidikan, Jakarta: Grafindo Persada, 2006.

Syaiful H. Sagala, Konsep dan Makna Pembelajaran, Bandung: Alfabeta, 2002.

Syaifurrahman dan Tri Ujiati, Manajemen Dalam Pembelajaran, Jakarta:Indeks, 2013.

Syamsu Yusuf LN., Psikologi Belajar Agama, Bandung: Pustaka Bani Quraisy, 2005.

Tarsis Tarmuji, Pengembangan Diri, Yogyakarta: Liberty, 1998.

Toeti Soekamto dan Udin Saripudin Winataputra, Teori Belajar dan Model-model Pembelajaran, Jakarta: PAU-PPAI, Cet.2, 1996.

Tohirin, Psikologi Pembelajaran Pendidikan Agama Islam. Jakarta: Raja Grafindo Persada, 2006.

Trisnawati, Implementasi Model ARCS (attention, relevance, confidence, satisfaction) Dalam Pembelajaran PAI Di SMA $N$ l Brebes, Semarang: IAIN WALISONGO, 2008.

Himpunan Perundang-undangan Republik Indonesia Tentang Sistem Pendidikan Nasional (SISDIKNAS) Nomor 20 Tahun 2003, Bandung: Nuansa Aulia, 2010. Bambang Sudibyo, "Lampiran Peraturan Menteri Pendidikan Nasional Nomor 22 Tahun 2006", http://www.puskur.net/23052006/1pini.phtml 